\title{
CAPAIAN PEMBELAJARAN APRESIASI PROSA FIKSI YANG BERORIENTASI PADA LAPANGAN KERJA DI ERA REVOLUSI INDUSTRI 4.0
}

\author{
Elyusra $^{1}$ dan Rio Saputra ${ }^{2}$ \\ FKIP Universitas Muhammadiyah Bengkulu \\ elyusra@umb.ac.id; riosaputra@umb.ac.id
}

\begin{abstract}
Abstrak
Masalah yang akan dibahas dalam penelitian ini adalah Capaian Pembelajaran mata kuliah Apresiasi Prosa Fiksi yang berorientasi pada lapangan kerja di era revolusi industri 4.0, berupa hasil identifikasi Capaian Pembelajaran Lulusan yang dibebankan pada mata kuliah, rumusan Capaian Pembelajaran Mata Kuliah (CPMK), dan sub-CPMK pada Program Studi Pendidikan Bahasa dan Sastra Indonesia (PS PBSI) Universitas Muhammadiyah Bengkulu (UMB). Metode penelitian adalah deskriptif-kualitatif. Sumber data adalah dokumen kurikulum Progran Studi Pendidikan Bahasa dan sastra Indonesia PS PBSI, bahan ajar apresiasi prosa fiksi yang dikomersialkan, artikel-artikel dalam jurnal ilmiah, serta teks-teks gagasan atau pemikiran tentang lapangan kerja tamatan PS PBSI. Data diperoleh dengan studi dokumentasi dan studi kepustakaan. Hasil penelitian menyatakan bahwa CPL yang dibebankan pada mata kuliah Apresiasi Prosa Fiksi berjumlah enam CPL, terdiri atas pengetahuan, sikap, keterampilan umum, dan keterampilan khusus, dispesifikasikan menjadi enam CPMK dan sepuluh sub-CPMK. Sepuluh sub-CPMK yang dirumuskan mencakup berbagai kawasan dan tingkatan tujuan pendidikan; mencakup berbagai kegiatan dan tingkatan apresiasi sastra, bermuatan dengan kompetensi yang dibutuhkan di era revolusi 4.0, sehingga memungkinkan mahasiswa menjalankan profesi yang ada di era revolusi industri 4.0, terutama yang berbasis bahasa dan sastra.
\end{abstract}

\section{Kata kunci: Capaian Pembelajaran, Apresiasi Prosa Fiksi, Revolusi Industri 4.0, Lapangan Kerja Tamatan PS} PBSI.

\begin{abstract}
The problem to be discussed in this study is the Learning Achievement of Fiction Prose Appreciation courses that are work oriented in the era of the industrial revolution 4.0, in the form of the identification of Graduates' Learning Achievement charged to the subjects, the formulation of Subject Learning Achievement (CPMK), and sub-CPMK in the Indonesian Language and Literature Education Study Program (PS PBSI) Muhammadiyah University Bengkulu (UMB). The research method is descriptive-qualitative. Data sources are PS PBSI Indonesian Language and Literature Education Study Program curriculum documents, commercialized fiction appreciation teaching materials, articles in scientific journals, as well as texts of ideas or thoughts about the employment of PS PBSI graduates. Data obtained by documentation studies and literature studies. The results of the study stated that the CPL charged to the Prose Fiction Appreciation course totaled six CPL, consisting of knowledge, attitudes, general skills, and special skills, specified into six CPMKs and ten sub-CPMKs. The ten sub-CPMKs that were formulated covered various regions and levels of educational objectives; covers a variety of activities and levels of literary appreciation, charged with competencies needed in the 4.0 revolution era, thus enabling students to carry out professions that existed in the industrial revolution 4.0 era, especially those based on language and literature.
\end{abstract}

Keywords: learning achievements, fiction prose appreciation, industrial revolution 4.0, PS PBSI graduate employment.

\section{PENDAHULUAN}

Artikel ini merupakan salah satu luaran kegiatan Penugasan Dosen di Sekolah tahun 2019 yang penulis ikuti. Sebagai alumni dosen model Program PDS tahun 2018, pada Program Hibah PDS tahun 2019 ini penulis mendapat kesempatan menerapkan hasil program PDS tahun 2018 di dalam mata kuliah yang penulis ampu. Pada tahun 2018 secara kolaboratif dengan guru model di SDIT Iqra’ Kota Bengkulu, diterapkan model TERPADU dengan metode diskusi berbantuan kartu untuk peningkatan pengelolaan pembelajaran. Pada mata kuliah Apresiasi Prosa Fiksi yang penulis ampu pada semester ini diterapkan pengalaman sebagai dosen model Program PDS tahun 2018 
tersebut. Baik sebagai dosen model di sekolah, maupun sebagai dosen model di LPTK yang harus menjalankan peran meningkatkan kualitas pembelajaran, maka dosen model diwajibkan menyiapkan RPP untuk di sekolah, dan RPS untuk di LPTK.

Rancangan RPS yang disusun dosen harus berpedoman pada Capaian Pembelajaran Lulusan (CPL) yang dirumuskan program studi berdasarkan hasil penelusuran lulusan, masukan pemangku kepentingan, asosiasi profesi, konsorsium keilmuan, kecenderungan keilmuan/keahlian ke depan, dan dari hasil evaluasi. tahapan yang cukup panjang dan ketat, serta dengan ketentuanketentuan yang cukup beragam. Dengan demikian, CPL yang sudah ditetapkan oleh program studi benar-benar harus menjadi landasan, panduan, dan arah bagi setiap dosen yang akan mengembangkan RPS mata kuliah yang diampunya.

Tahapan pengembangan pembelajaran yang termuat dalam Panduan Penyusunan Kurikulum Perguruan Tinggi berorientasi kepada model perancangan pembelajaran Dick \& Carey (Dirjen Belmawa, 2018: 33-34). Menetapkan Capaian Pembelajaran adalah langkah yang harus dilakukan sebelum menentukan instrumen penilaian, metode, dan materi pembelajaran, bahkan Capaian Pembelajaran merupakan aspek yang akan mengarahkan dan menentukan penetapan aspek-aspek pembelajaran tersebut.

Dosen yang sudah lama mengampu mata kuliah Apresiasi Sastra atau yang lebih spesifik lagi seperti: Apresiasi Puisi, Apresiasi Prosa Fiksi, dan Apresiasi Drama, harus melakukan rekonstruksi mata kuliah. Hasil analisis terhadap rancangan pembelajaran mata kuliah Apresiasi sastra yang disusun oleh dosen di beberapa perguruan tinggi menyatakan bahwa sebagian besar dosen sudah merancang pembelajaran mata kuliah Apresiasi Sastra yang diampunya dengan orientasi pada Panduan Penyusunan Kurikulum Perguruan Tinggi yang ditetapkan oleh Dirjen Belmawa tahun tahun 2016 atau hasil revisi tahun 2018. Hal ini ditandai dengan nama dokumen sebagai RPS, penggunaan istilah CPL, CPMK, Sub-CPMK, serta penggunaan format RPS yang disarankan dalam panduan. Akan tetapi, CPMK dan Sub-CPMK yang dirumuskan belum sepenuhnya memperhatikan kemampuan yang dibutuhkan lulusan perguruan tinggi yang diperlukan dalam era industri 4.0, seperti literasi data, literasi teknologi, literasi manusia, serta kemampuan memandang tanda-tanda akan terjadinya revolusi industri 5.0. Selain itu, perkembangan industri kreatif juga belum banyak menjadi orientasi pengembangan CPMK dan Sub-CPMK oleh para dosen dalam menyusun RPS mata kuliah Apresaiasi Sastra yang diampu.

Dari beberapa RPS yang sudah dibuat, diketahui bahwa, pada umumnya CPMK dan SubCPMK mata kuliah Apresiasi Sastra (Puisi, Prosa Fiksi, dan drama) berkisar pada: hakikat apresiasi sastra, tahapan apresiasi sastra, jenis apresasi sastra, struktur karya sastra (puisi, prosa fiksi, dan drama), pendekatan dalam apresiasi sastra, pengajaran apresiasi sastra, yang semuanya berada pada domain pengetahuan. Diakui bahwa, melaksanakan kegiatan apresiasi sastra dibutuhkan bekal 
pengetahuan tentang kehidupan dan ilmu pengetahuan lain pada umumnya; pengetahuan mengenai manusia, dan pengetahuan tentang seluk- beluk jenis karya sastra yang diapresiasi (Suharianto,1981).

Apresiasi sastra sebagai kegiatan atau usaha pengenalan baik fisik atau mental untuk merasakan, memahami secara tepat nilai-nilai sastra, serta memberikan pertimbangan atau penilaian dengan kegairahan, serta kenikmatan yang timbul sebagai akibat dari semua itu (Rusyana, 1979; Suhartianto, 1981:15; Atmazaki,1993:133-134). Kegiatan apresiasi dapat berupa kegiatan langsung, kegiatan tidak langsung, dokumentatif, dan kreatif. Sebagai suatu proses, kegiatan apresiasi sastra memiliki empat tingkatan, yakni: tingkat menggemari, tingkat menikmati,tingkat mereaksi, dan tingkat memproduksi (Wardani, 1981). Tingkat menggemari dapat diperoleh dengan pembiasaan, tingkat menikmati berupa merasakan keindahan karya, mereaksi berupa menampilkan kembali karya, dan tingkat memproduksi adalah menghasilkan karya. Dari konsep apresiasi ini, dapat dinyatakan, bahwa CP yang hendak diwujudkan, hendaknya mencakup berbagai macam kegiatan apresiasi dalam berbagai tingkatan pula.

Rekonstruksi mata kuliah Apresiasi Prosa Fiksi semakin penting dilakukan mengingat Profil Program Studi Pendidikan Bahasa dan Sastra Indonesia (PBSI) yang sudah mengalami perubahan. Program Studi PBSI tidak lagi semata-mata menghasilkan lulusan untuk menjadi guru Bahasa Indonesia di sekolah-sekolah, namun juga mampu menjadi peneliti dan wirausahawan di bidang bahasa dan sastra Indonesia serta pengajarannya. Rumusan CPMK dan sub-CPMK mata kuliah Apresiasi Prosa Fiksi dimaksud dengan orientasi lapangan kerja di era Revolusi Industri 4.0.

Penelitian terhadap pengembangan pembelajaran sastra, yang memungkinkan mahasiswa mampu berperan di lapangan kerja yang beragam di era revolusi industri 4.0 telah dilakukan oleh Prawoto dan Pramulia (2019: 41). Melalui pembelajaran sastra berbasis blended learning yang dikembangkannya dinyatakan bahwa mahasiswa selain mampu memaknai karya sastra dengan baik, mereka juga mampu mentransformasi karya sastra ke dalam bentuk lain, serta terampil berteknologi, seperti belajar mengolah vidio, MP3, dan membuat gambar jpg. Akan tetapi, penelitian ini tidak secara khusus mengkaji mata kuliah Apresiasi Prosa Fiksi, yang menghendaki rumusan CPMK dan Sub-CPMK yang spesifik untuk dikuasai mahasiswa.

Penelitian terhadap pembelajaran sastra Indonesia yang berorientasi pada era revolusi 4.0 dan Sociatry 5.0, khususnya dalam menciptakan peluang kewirausahaan berbasis bahasa dan sastra Indonesia dilakukan oleh Wurianto (2019). Solusi yang dapat ditempuh untuk merebut peluang adalah dengan melakukan diservikasi keterampilan berbahasa dan bersastra berbasis teknologi, informasi, industri dan humanisasi. Strategi yang ditawarkan bersifat makro, yakni berupa menumbuhkan kesadaran long life education, educability, keluasan pemilihan pengalaman belajar, exposure to broad areas of learning, integrasi situasi pendidikan dan pengalaman belajar. Dengan 
demikian, hasil penelitian ini juga belum memberikan informasi yang spesifik tentang CPMK dan Sub-CPMK mata kuliah Apresiasi Prosa Fiksi, khususnya di Fakultas Keguruan dan Ilmu Pendidikan (FKIP).

Dengan demikian, sangatlah penting dirumuskan CPMK dan Sub-CPMK untuk mata kuliah Apresiasi Prosa Fiksi, khususnya yang ditawarkan di FKIP Universitas Muhammadiyah Bengkulu. Kekhususan rumusan CPMK dan Sub-CPMK ini juga membuka peluang berlaku secara universal, atau dapat diadopsi untuk diterapkan di perguruan tinggi lain, karena adanya landasan atau acuan yang bersifat umum yang dipedomani dalam merumuskannya, yakni berupa asosiasi profesi, konsorsium keilmuan, kecenderungan keilmuan/keahlian ke depan, dan Panduan Penyusunan Kurikulum Pendidikan Tinggi di Era Industri 4.0 yang diterbitkan oleh Kementerian Riset, Teknologi dan Pendidikan Tinggi tahun 2018 yang menyatakan bahwa CPL suatu program studi harus memuat kemampuan yang diperlukan dalam era industri 4.0 tentang literasi data, literasi teknologi, literasi manusia, serta kemampuan memandang tanda-tanda akan terjadinya revolusi industri 5.0 (Kemenristek Dikti, 2018: 20).

\section{METODE PENELITIAN}

Subjek penelitian ini adalah konsep-konsep, prinsip-prinsip, prosedur, dan tata nilai yang merupakan indikator CPMK Apresiasi Prosa Fiksi, yang terdapat dalam: 1) Panduan Penyusunan Kurikulum Pendidikan Tinggi di Era Industri 4.0 yang diterbitkan oleh Kementerian Riset, Teknologi dan Pendidikan Tinggi tahun 2018; 2) kurikulum Program Studi PBSI, 3) buku referensi apresiasi sastra dan apresiasi prosa fiksi yang dikomersialkan, 4) teks yang berkenaan dengan Revousi Industri 4.0, dan 4) teks tentang lapangan kerja bagi tamatan program studi Pendidikan Bahasa dan Sastra Indonesia. Data diperoleh dari Panduan Penyusunan Kurikulum Pendidikan Tinggi di Era Industri 4.0, dokumen kurikulum Program Studi PBSI Universitas Muhammadiyah Bengkulu, buku referensi apresiasi sastra dan apresiasi prosa fiksi yang dikomersialkan, serta artikel dalam jurnal yang berkenaan dengan Revousi Industri 4.0, dan artikel tentang lapangan kerja bagi tamatan program studi Pendidikan Bahasa dan Sastra Indonesia.

Metode pengumpulan data dilakukan dengan studi dokumentasi untuk identifikasi CPL yang dibebankan pada mata kuliah dan observasi untuk studi pustaka terkait kurikulum Pendidikan Tinggi di era revolusi industri 4.0. Studi pustaka juga dilakukan untuk identifikasi materi apresiasi prosa fiksi dalam buku, dalam artikel-artikel jurnal. Metode analisis data menggunakan deskriptif kualitatif, dengan tiga kegiatan pokok: 1) mengidentifikasi CPL yang dibebankan pada mata kuliah,

2) merumuskan Capaian Pembelajaran Mata Kuliah (CPMK), dan 3) merumuskan sub-CPMK (Dirjen Belmawa, 2018: 33-34). Untuk mendukung tiga kegiatan pokok tersebut dilakukan 
identifikasi dan pemaknaan, pengkodingan, kategorisasi, dan penyusunan CPMK dan sub- CPMK yang diinginkan. Validitas data diperoleh dengan ketekunan pengamatan.

\section{HASIL PENELITIAN DAN PEMBAHASAN}

\section{a. Revolusi Industri 4.0}

Revolusi industri 4.0 pertama kali dikenalkan oleh Prof. Klaus Schwab, seorang Founder dan Executive Chairman dari World Economic Forum. Menuruf Schwab, revolusi industri keempat tidak hanya tentang mesin dan sistem cerdas yang saling terhubung, tetapi juga terjadinya secara simultan gelombang dobrakan dalam berbagai area mulai dari pengurutan gen hingga teknologi nano; energi terbarukan hingga komputasi kuantum (Schwab, 2016). Survey PWC menyebutkan bahwa tantangan terbesar implementasi revolusi industri 4.0 bukanlah menemukan teknologi yang tepat, tetapi kurangnya budaya dan kemampuan digital dalam organisasi (PWC, 2016). Pendidikan tinggi mulai menjalankan perannya untuk membangun kesadaran tentang perangkat-perangkat yang saling berkomunikasi baik melalui media internet maupun sensor, sehingga integrasi industri 4.0 dengan pendidikan tinggi akan meningkatkan kualitas Pendidikan (Baygin, Yetis, Karakose, \& Akin, 2016).

Perkembangan revolusi industri turut menyebabkan perubahan dalam bidang-bidang lain, termasuk pemasaran. Konsep Marketing 4.0 adalah pendekatan pemasaran yang mengombonasi konektivitas mesin-ke-mesin dengan sentuhan orang-ke-orang untuk menguatkan keterikatan konsumen (Kotler, Kertajaya, Setiawan, \& Iwan, 2017). Dewasa ini, semakin banyak media komersial yang memadukan sentuhan-sentuhan kemanusiaan dengan canggihnya teknologi. Sebagai contoh, iklan Tokopedia “berikan yang paling berarti untuk yang berarti” menjelaskan seorang Ayah yang sangat serius membuatkan jam untuk anaknya, mengabaikan keinginan sang anak untuk bepergian ke rumah eyangnya, dan akhirnya tidak mengikuti perkembangan sang anak (Tokopedia, 2019). Tokopedia digambarkan sebagai sarana untuk “memulai” setiap keinginan.

Revolusi industri merupakan era disruptif. Era tersebut ditandai dengan berbagai macam aktivitas manusia akan mengalami disruptif. Beberapa bidang kehidupan yang akan terdampak adalah bidang ilmu pengetahuan, teknologi, pendidikan, dan seni (Suwandi, 2019) Bidang seni di era industri 4.0 ditandai dengan berkembangnya industri kreatif. Dalam hal ini, seni sastra, yang sekaligus merupakan bidang olah bahasa, berkembang cukup pesat. Dengan demikian, dalam merumuskan CPMK atau Sub-CPMK mata kuliah Apresiasi Prosa Fiksi, perlu memperhatikan tiga literasi baru yang disarankan Direktorat Pembelajaran (2018) yang telah dikemukakan di atas. Aspek-aspek digital, teknologi, dan kemanusiaan perlu mendapat perhatian. Literasi digital diarahkan pada tujuan peningkatan kemampuan membaca, menganalisis, dan menggunakan informasi di dunia digital (big data), literasi teknologi bertujuan untuk memberikan pemahaman 
pada cara kerja mesin dan aplikasi teknologi, dan literasi manusia diarahkan pada peningkatan kemampuan berkomunikasi dan penguasaan ilmu desain (Aoun dalam Suwandi, 2017).

\section{b. Lapangan Kerja Lulusan Program Studi Pendidikan Bahasa dan Sastra Indonesia di Era Revolusi Industri 4.0}

Banyak yang sudah menginventarisasi lapangan kerja lulusan Program Studi Pendidikan Bahasa dan Sastra Indonesia. Zamhari mengemukakan sebuah daftar panjang tentang prospek lulusan Program Studi ini. Lapangan kerja dimaksud yaitu: jurnalis, bidang perbankan, pegawai penyiaran umum, mengelola sosial media, penulis profesional, blogger, staf perhotelan dan pariwisata, guru Bahasa Indonesia, editor atau penyunting redaksi, seniman sastra, pegawai di instansi pemerintah, Sales marketing, pegawai perusahaan periklanan, pengusaha start up. https://www.renesia.com/10-peluang-atau-prospek-kerja-sastra-indonesia/

Daftar di atas masih dapat ditambah dengan beberapa jenis pekerjaan lagi, seperti: penerjemah, penulis novel atau cerpen, guru Bahasa Indonesia, penerjemah bahasa, dosen Bahasa Indonesia, penulis script film, pengusaha percetakan, artis/ pemeran drama, dan leksikografer. https://www.renesia.com/10-peluang-atau-prospek-kerja-sastra-indonesia/.

Sugono (2014: 12-13) mengungkapkan, dengan bahasa, manusia dapat memenuhi berbagai kebutuhan jasmani, bekerja, dan hidup sebagai makhluk sosial, maupun keperluan rohani. Ia menambahkan, dengan bahasa, manusia dapat melakukan aktivitas berpikir secara optimal, sebagai sarana berpikir dan berekspresi. Oleh sebab itu, bahasa memiliki kekuatan luar biasa dalam kehidupan manusia, baik dengan sesama manusia, manusia dengan alam, dan manusia dengan Tuhannya. Inilah yang menjadikan lulusan Program Studi Pendidikan Bahasa dan Sastra Indonesia di Era Revolusi Industri 4.0 memiliki prospek kerja yang banyak.

Quipper merilis gaji penulis di media sosialnya sebesar Rp 3.000.000 - Rp 4.500.000 untuk lulusan SMA/SMK sederajat. Gaji ini perkiraan penghasilan untuk level awal. Jumlah ini masih memiliki variasi tergantung kebijakan perusahaan dan trend industri (https://campus.quipper.com/careers/penulis). Untuk profesi tour guide yang bersertifikat dari asosiasi, besar penghasilan rata-rata Rp 450.000 sehari. Kemudian kalau sudah expert itu dapat mencapai satu sampai lima juta rupiah sehari (Garjito, 2019).

Diungkapkan IDN Times empat penulis Indonesia yang mendapatkan kekayaan dari pekerjaan menulis novel. (https://www.idntimes.com/hype/fun-fact/muro/fantastis-4-penulisindonesia-ini-kaya-raya-dari-hasil-menulis-novel-c1c2/full. Andrea Hirata dapat menghasilkan keuntungan hingga 3,6 miliar rupiah hanya dari satu judul novel. Habiburahman El-Shirazy mampu meraup hingga mencapai 2,4 miliar rupiah hanya dari satu judul novelnya Ayat-ayat Cinta. Penghasilan Dewi Lestari mencapai 1,5 miliar rupiah lebih dari hasil menulis novel. Tere Liye pun 
menghasilkan miliaran rupiah dari menulis. Ini baru hasil dari satu novel, belum dijumlahkan dari novel-novel best seller yang mereka hasilkan.

Berapa jumlah penghasilan Blogger Indonesia dari Google AdSense per bulan? Jawabannya: relatif. Namun, diperkirakan antara Rp1-5 juta per bulan, tergantung pada trafik atau jumlah pengunjung blognya. Ini perkiraan penghasilan dalam dunia menulis blog. Penghasilan seorang youtuber lebih fantastis lagi. Dulu mencari uang dengan kerja keras, sekarang mencari uang dengan kerja cerdas. Mereka memilih menjadi youtubers, upload, membuat video blog (vlog), kemudian tunggu viewers maka mereka akan mendapatkan uang dari hasil videonya. (Saputra, 2019). Sejumlah media memberikan estimasi penghasilan Ria Ricis dari iklan di Youtube tembus antara Rp 500 juta hingga Rp 1 milyar per bulan - sebuah angka yang fenomenal (Antariksa, 2019).

Antariksa (2019) memberikan gambaran biaya iklan di televisi selama 30 detik rata-rata sekitar Rp 50.000.000. Jika sebuah brand, memasang iklan sebanyak 10 kali per hari, maka biayanya dapat mencapai Rp 500.000.000 per hari. Suatu jumlah yang cukup besar dalam satu bulan, apalagi kalau dikalikan dengan ratusan brand yang pasang iklan. Semua ini memerlukan media bahasa, baik keterampilan berbicara, menulis dalam membuat konten kreatif, dan membaca untuk menyajikan data pendukung serta riset sebuah topik yang akan ditayangkan.

Dari penjelasan di atas, dapat dipahami bahwa lapangan kerja lulusan Program studi Pendidikan Bahasa dan Sastra Indonesia di era revolusi industri 4.0 sangat bervariasi. Hal ini disebabkan karena kekuatan bahasa diperlukan hampir di segala bidang kehidupan. Penghasilan yang didapatkan juga tidak sedikit, tergantung tingkat kreativitas yang dimiliki seseorang dalam mengolah bahasa dan sastra dalam industri kreatif kebahasaan.

\section{c. Materi Apresiasi Prosa Fiksi dalam RPS dan Bahan Ajar Komersial}

Dalam RPS yang sudah disusun diidentifikasi capaian pembelajaran yang cenderung pada penguasaan teori apresiasi prosa fiksi dan pemahaman karya prosa fiksi berupa prosa lama, novel, dan cerpen. Capaian Pembelajaran MK dan sub-CPMK yang merupakan keterampilan khusus seperti: menulis antologi karya prosa fiksi, membuat majalah sastra, menunjukkan persentase yang sangat rendah, apalagi kemampuan yang aktual, seperti fiksi lintasmedia. Capaian Pembelajaran Mata Kuliah atau Sub-CPMK yang berkenaan dengan penciptaan karya fiksi dengan karakteristik sastra siber pun belum menjadi perhatian, seperti menulis bentuk cerpen pendek dan fiksi mini. Demikian juga kompetensi-kompetensi yang mencerminkan keunikan masing-masing perguruan tinggi dan keunikan daerah. Kemampuan dalam mata kuliah Apresiasi Prosa Fiksi di perguruan tinggi dengan profil islami dalam visi dan misinya, dapat menetapkan "bercerita islami” sebagai kemampuan yang harus dikuasai mahasiswa. Kemampuan sikap yang konkrit yang harus dimiliki mahasiswa juga jarang ditemukan dalam RPS yang disusun oleh para dosen. 
Selain RPS mata kuliah Apresiasi Prosa Fiksi, yang belum mendapatkan revisi yang signifikan dari dosen, buku referensi atau bahan ajar mata kuliah Apresiasi Prosa Fiksi yang dijual secara komersial menunjukkan hal yang sama. Materi yang termuat dalam buku referensi atau bahan ajar komersial tersebut juga berkisar pada: teori prosa fiksi, dengan cakupan pengertian prosa fiksi, unsur-unsur pembangun prosa fiksi, dan jenis prosa fiksi. Materi lain yang disusun lebih cenderung pada pemahaman karya prosa fiksi berdasarkan beberapa pendekatan (Aminuddin, 2010; Saryono, 2009; Suyitno, 2009; Yandianto: 2004).

Secara khusus, telah ditulis buku Panduan Apresiasi Cerpen untuk Siswa dan Mahasiswa dengan orientasi globalisasi, keseimbangan tiga mantra pendidikan (kognitif, afektif, dan psikomotor), dan kreativitas (Sumardi, 2012; 17-25). Dalam buku ini juga sudah muncul beragam kegiatan apresiasi cerpen, berupa kegiatan menikmati cerpen, memahami cerpen, membacakan cerpen, menghadiri pembacaan cerpen, serta merefeksikan pengalaman menikmati cerpen (Sumardi, 2012: 67-83). Penulis buku sudah mengemukakan tujuan-tujuan yang dapat dicapai melalui kegiatan-kegiatan apresiasi di atas. Akan tetapi, rumusan secara konkrit CPMK dan subCPMK tidak diberikan.

Dari paparan di atas, diketahui bahwa materi yang disusun dalam buku-buku referensi tersebut hanya mampu mencapai kemampuan-kemampuan yang berupa pengetahuan, sikap, dan keterampilan yang kurang aktual sehingga tidak mampu membekali mahasiswa untuk memasuki lapangan kerja yang cukup beragam di era revolusi industri 4.0. Oleh sebab itu, perlu disusun diidentifikasi CPL yang dibebankan pada pada kuliah, CPMK, dan sub-CPMK Apresiasi Prosa Fiksi.

\section{d. Capaian Pembelajaran Mata Kuliah Apresiasi Prosa Fiksi yang Berorientasi pada lapangan Kerja di Era Revolusi Industri 4.0: suatu alternatif}

Program Studi Pendidikan Bahasa dan Sastra Indonesia FKIP UMB memiliki visi “Menjadi Program Studi Pendidikan Bahasa dan Sastra Indonesia yang unggul dalam IPTEKS dan menghasilkan sarjana pendidikan yang berkualitas, islami, serta berjiwa kewirausahaan pada tahun 2022”. Profil Lulusan Sarjana Pendidikan Bahasa dan Sastra Indonesia FKIP UMB adalah menjadi: 1) Pendidik pemula bahasa dan sastra Indonesia yang islami, 2) Peneliti pemula bahasa dan sastra Indonesia yang islami, dan 3) Wirausahawan bidang bahasa dan sastra Indonesia serta pembelajarannya yang islami (UMB, 2018: 4 dan 8)

Merumuskan Capaian Pembelajaran Mata Kuliah dilakukan dengan kegiatan mengidentifikasi CPL yang ditetapkan program studi yang dibebankan pada mata kuliah. Capaian Pembelajaran Lulusan ini sudah dicantumkan dalam Capaian Pembelajaran Lulusan Program Studi 
yang terdiri atas:12 kemampuan sikap dan tata nilai, 5 penguasaan pengetahuan, 10 keterampilan umum, dan 6 keterampilan khusus (UMB, 2018: 8-10).

\section{1) Mengidentifikasi CPL yang dibebankan pada Mata kuliah}

Berdasarkan hasil identifikasi CPL Program Studi di atas, CPL yang dibebankan pada mata kuliah Apresiasi Prosa Fiksi adalah sebagai berikut:

Tabel 1. CPL Prodi S1 Pendidikan Bahasa dan Sastra Indonesia FKIP UMB

\begin{tabular}{|c|c|}
\hline Kode & CPL Prodi S1 Pendidikan Bahasa dan Sastra Indonesia \\
\hline \multicolumn{2}{|c|}{ SIKAP (S) } \\
\hline S5 & $\begin{array}{l}\text { Menghargai keanekaragaman budaya, pandangan, agama dan kepercayaan, } \\
\text { serta pendapat, atau temuan orisinal orang lain. }\end{array}$ \\
\hline S12 & $\begin{array}{l}\text { Mengimplementasikan nilai-nilai keislaman dan kemuhammadiyahan dalam } \\
\text { pembelajaran bahasa dan sastra Indonesia }\end{array}$ \\
\hline \multicolumn{2}{|c|}{ PENGETAHUAN (P) } \\
\hline P1 & $\begin{array}{l}\text { Menguasai konsep-konsep dasar kebahasaan dan kesastraan, keterampilan } \\
\text { berbahasa dan bersastra, pembelajaran bahasa dan sastra, penelitian bahasa } \\
\text { dan sastra, serta penelitian pendidikan bahasa dan sastra. }\end{array}$ \\
\hline \multicolumn{2}{|c|}{ KETERAMPILAN UMUM (KU) } \\
\hline KU2 & Mampu menunjukkan kinerja mandiri , bermutu, dan terukur. \\
\hline \multicolumn{2}{|c|}{ KETERAMPILAN KHUSUS (KK) } \\
\hline KK2 & $\begin{array}{l}\text { Mampu mengapresiasi, mengekspresi, mengkreasi karya sastra Indonesia } \\
\text { secara lisan dan tulis. }\end{array}$ \\
\hline KK5 & $\begin{array}{l}\text { Mampu menghasilkan layanan jasa dan produk kreatif dalam bidang bahasa } \\
\text { dan sastra Indonesia, serta pembelajarannya }\end{array}$ \\
\hline
\end{tabular}

Komponen-komponen CPL yang harus dikaji menurut Robert M. Gagne, setidaknya ada lima, yaitu: 1) tipe kemampuan belajar (capability verb), 2) kata kerja tindakan (action verb), 3) objek kinerja (the object of performance) pembelajaran, 4) perangkat, kendala atau kondisi khusus yang diperlukan dalam pembelajaran, 5) situasi belajar (2018).

\section{2) Merumuskan Capaian Pembelajaran Mata Kuliah (CPMK) dan Sub-CPMK}

Dalam hal merumuskan CPMK dan sub-CPMK, harus mengandung unsur-unsur kemampuan dan materi pembelajaran yang dipilih dan ditetapkan tingkat kedalaman dan keluasannya, serta mengemukakan pula konteks. Tingkat kedalaman dan keluasan materi pada lulusan program diploma empat dan sarjana yang ditetapkan paling sedikit ditandai dengan “ 
menguasai konsep teoritis bidang pengetahuan dan keterampilan tertentu secara umum dan konsep teoritis bagian khusus dalam bidang pengetahuan dan keterampilan tersebut secara mendalam”.

Capaian Pembelajaran Mata Kuliah yang dapat dirumuskan berdasarkan CPL yang dibebankan pada mata kuliah Apresiasi Prosa Fiksi tersaji pada tabel berikut:

Tabel 2. CPMK Mata Kuliah Apresiasi Prosa Fiksi yang Dirumuskan Berasarkan CPL

\begin{tabular}{|l|l|}
\hline \multicolumn{1}{|c|}{ Kode } & \multicolumn{1}{c|}{ Capaian Pembelajaran Mata Kuliah } \\
\hline CPMK1 & $\begin{array}{l}\text { Menghargai prosa fiksi hasil cipta sastrawan Indonesia sebagai produk } \\
\text { budaya dan temuan original orang lain dan mengomunikasikannya secara } \\
\text { lisan dan tulisan secara mandiri, bermutu, dan terukur (S5, S12); }\end{array}$ \\
\hline CPMK2 & $\begin{array}{l}\text { Mampu memahami konsep-konsep, definisi-definisi, prinsip-prinsip, dan } \\
\text { kategori-kategori apresiasi prosa fiksi secara mandiri, bermutu, dan } \\
\text { terukur (P1, KU2); }\end{array}$ \\
\hline CPMK3 & $\begin{array}{l}\text { Mampu mendokumentasikan karya-karya prosa fiksi yang dipublikasikan } \\
\text { pada media massa (cetak dan elektronik) dengan teknik yang baik dan } \\
\text { tampilan yang menarik, serta memberikan tanggapan terhadap karya } \\
\text { dengan berbagai pendekatan (S5, KU2,KK2); }\end{array}$ \\
\hline CPMK4 & $\begin{array}{l}\text { Mampu menampilkan karya prosa fiksi Indonesia di depan audien dengan } \\
\text { teknik yang baik, menarik, dan kreatif, baik secara mandiri maupun secara } \\
\text { kolaborasi (KU2, KK2,KK5) }\end{array}$ \\
\hline CPMK6 & $\begin{array}{l}\text { Mampu menghasilkan produk kreatif yang berbasis karya prosa fiksi } \\
\text { Indonesia dengan tema yang baik, teknik yang baik, kemasan yang } \\
\text { menarik, serta menggunakan bahasa Indonesia yang benar melalui kerja } \\
\text { KKandiri dan kolaborasi (S12, P1, KU2, KK2,KK5) }\end{array}$ \\
\hline CPMK5
\end{tabular}

Enam CPMK yang sudah dirumuskan di atas, perlu dikembangkan lebih lanjut menjadi subCPMK, seperti tersaji dalam tabel berikut.

Tabel 3. Sub-CPMK Mata Kuliah Apresiasi Prosa Fiksi yang Dirumuskan Berasarkan CPMK

\begin{tabular}{|l|l|}
\hline \multicolumn{1}{|c|}{ Kode } & \multicolumn{1}{c|}{ Capaian Pembelajaran Mata Kuliah } \\
\hline Sub-CPMK1 & $\begin{array}{l}\text { Menghargai prosa fiksi hasil cipta sastrawan Indonesia dengan cara } \\
\text { memilikinya, menganalisis, menginterpreasi, menanggapi, serta } \\
\text { mengomunikasikannya secara lisan dan tulisan (CPMK1) }\end{array}$ \\
\hline
\end{tabular}




\begin{tabular}{|c|c|}
\hline Sub-CPMK2 & $\begin{array}{l}\text { Mampu memahami konsep-konsep dasar apresiasi prosa fiksi berupa } \\
\text { pengertian/ definisi apresiasi prosa fiksi, macam-macam kegiatan } \\
\text { apresiasi prosa fiksi, tujuan dan manfaat apresiasi prosa fiksi, } \\
\text { pendekatan dalam mengapresiasi prosa fiksi dengan secara mandiri, } \\
\text { bermutu dan terukur (CPMK2); }\end{array}$ \\
\hline Sub-CPMK3 & $\begin{array}{l}\text { Mampu mendokumentasikan karya-karya prosa fiksi yang } \\
\text { dipublikasikan pada media massa (cetak dan elektronik) dalam bentuk } \\
\text { kliping kompleks dengan teknik yang baik dan tampilan yang menarik, } \\
\text { serta memberikan tanggapan terhadap karya dengan berbagai } \\
\text { pendekatan (CPMK3); }\end{array}$ \\
\hline Sub-CPMK4 & $\begin{array}{l}\text { Mampu menampilkan pembacaan karya prosa fiksi Indonesia di depan } \\
\text { audien dengan teknik yang baik, menarik, dan kreatif, baik secara } \\
\text { mandiri maupun secara kolaborasi (CPMK4) }\end{array}$ \\
\hline Sub-CPMK5 & $\begin{array}{l}\text { Mampu mendongeng di depan audien dengan teknik yang baik, } \\
\text { menarik, dan kreatif, baik secara mandiri maupun secara kolaborasi } \\
\text { (CPMK4) }\end{array}$ \\
\hline Sub-CPMK6 & $\begin{array}{l}\text { Mampu bercerita islami di depan audien dengan teknik yang baik, } \\
\text { menarik, dan kreatif, baik secara mandiri maupun secara kolaborasi } \\
\text { (CPMK4); }\end{array}$ \\
\hline Sub-CPMK7 & $\begin{array}{l}\text { Mampu membuat antologi karya prosa fiksi Indonesia dengan tema } \\
\text { yang baik, teknik yang baik, kemasan yang menarik, serta } \\
\text { menggunakan bahasa Indonesia yang benar melalui kerja mandiri dan } \\
\text { kolaborasi (CPMK5); }\end{array}$ \\
\hline Sub-CPMK8 & $\begin{array}{l}\text { Mampu membuat sebuah fiksi lintasmedia dengan teknik yang baik } \\
\text { dan menarik secara kolaboratif (CPMK 5) }\end{array}$ \\
\hline Sub-СРMK9 & $\begin{array}{l}\text { Mampu membuat majalah sastra prosa fiksi Indonesia dengan tema } \\
\text { yang baik, teknik yang baik, kemasan yang menarik, serta } \\
\text { menggunakan bahasa Indonesia yang baik melalui kerja mandiri dan } \\
\text { kolaborasi (CPMK5); }\end{array}$ \\
\hline Sub-CPMK10 & $\begin{array}{l}\text { Mampu mengelola taman bacaan berbasis karya prosa fiksi dengan } \\
\text { pengelolaan yang baik, teknik yang baik, dan menarik, serta terukur } \\
\text { secara mandiri maupun kolaborasi (CPMK6). }\end{array}$ \\
\hline
\end{tabular}

Dalam sepuluh sub-CPMK di atas sudah tercakup berbagai ragam kegiatan apresiasi sastra. Ada empat macam kegiatan apresiasi sastra, yaitu: kegiatan langsung, kegiatan tidak langsung, 11| http://jurnal.umb.ac.id/index.php/lateralisasi 
kegiatan dokumentatif, dan kegiatan kreatif (Nurhadi, 2008: 13). Dalam Capaian pembelajaran membuat kliping kompleks (sub- CPMK3), tercakup: 1) kegiatan apresiasi langsung berupa membaca karya prosa fiksi yang dikliping; 2) merupakan kegiatan dokumentatif, berupa mengarsipkan karya prosa fiksi yang dipublikasikan dalam media massa, cetak dan elektronika; 3) melibatkan juga kegiatan apresiasi tidak langsung, yakni mempelajari konsep, prinsip, dan prosedur pengkajian sastra untuk membuat tanggapan terhadap karya yang dikliping.

Sepuluh sub-CPMK yang sudah dirumuskan di atas, sudah memenuhi semua kawasan tujuan pendidikan yang berorientasi pada Robert M. Gagne, yaitu keterampilan intelektual (intelectual skill), strategi kognitif (cognitive strategies), informasi verbal (verbal information), keterampilan motorik (motoric skills), serta sikap (attitude) yang disarankan oleh Dirjen Belmawa ( 2018: 34). Sub-CPMK 1 merupakan CP kawasan sikap dan tata nilai, Sub-CPMK 2 adalah CP kawasan informasi verbal. Sub-CPMK 3 berupa variasi kawasan keterampilan motorik dan informasi verbal, sedangkan sub-CPMK 4, 5, dan 6, merupakan CP pada kawasan keterampilan motorik. Sub-CPMK yang lain merupakan CP pada kawasan kognitif dan keterampilan motorik yang dirumuskan secara variatif.

Rumusan sub-CPMK di atas sudah sesuai dengan ketentuan yang diberikan, yang dinyatakan:

"Sub-CPMK merupakan "rumusan kemampuan akhir yang direncanakan pada tiap tahap pembelajaran untuk memenuhi CPL.... CPMK dan sub- CPMK bersifat dapat diamati, dapat diukur, dan dinilai, lebih spesifik terhadap mata kuliah, serta dapat didemonstrasikan oleh mahasiswa pada setiap tahapan belajar, dan secara komulatif menggambarkan pencapaian CPL yang dibebankan pada mata kuliah” (Dirjen Belmawa, 2018: 34).

Capaian pembelajaran ranah strategi kognitif dilaksanakan secara terintegrasi dalam kegiatan pembelajaran mencapai sub-CPMK-sub-CPMK yang sudah ditetapkan. Pada indikator pembelajaran mata kuliah ini ada satu tugas yang harus dikerjakan mahasiswa, yakni melaporkan ringkasan bahan pembelajaran dalam bentuk teksik peta pemikiran atau yang lebih dikenal dengan mind maap. Dalam mengerjakan tugas ini capaian pembelajaran kawasan strategi kognitif dapat dicapai, karena mahasiswa harus melakukan analisis dan seleksi informasi, membuat kategori, melabeli kategori informasi, dan menyajikannya kembali.

Karya- karya kreatif mahasiswa sebagai hasil akhir tahapan-tahapan pembelajaran dalam mata kuliah ini merupakan CP tingkat tinggi pada kawasan kognitif berdasarkan orientasi taksonomi Bloom yang sudah direvisi oleh Anderson dan Krathwohl, yang disarankan oleh Dirjen Belmawa ( 2018: 36). Ada enam tingkatan ranah tujuan pembelajaran kognitif, yaitu: 1) mengingat (remembering), 2) memahami/mengerti (understanding), menerapkan (appliying), menganalisis (analyzing), mengevaluasi (evaluating), dan menciptakan (creating) (dalam Gunawan dan Palupi, 
2012: 30). Kemampuan akhir pembelajaran berupa membuat buku antologi prosa fiksi dan membuat fiksi lintas media, merupakan CP tingkat creating (menciptakan).

Dalam sepuluh sub-CPMK mata kuliah Apresiasi Prosa Fiksi di atas, sudah diintegrasikan berbagai kompetensi yang dibutuhkan lulusan untuk dapat berhasil di lapangan kerja di era Revolusi Industri. Beragam kegiatan apresiasi yang harus dilakukan mahasiswa, dalam menyelesaikan tugas mata kuliah yang terdiri atas: membuat kliping kompleks; menulis beragam genre prosa fiksi, seperti novelet, cerpen, cerpen pendek, dan fiksi mini; memproduksi fiksi lintasmedia, menuntut mahasiswa senantiasa siap dengan ide-ide yang baru, agar karya yang mereka ciptakan menarik bagi pembaca atau penonton. "Ide” adalah hal yang krusial dalam era Revolusi Industri 4.0. Banyak kerja-kerja teknis dapat dilakukan oleh mesin, atau aplikasi-aplikasi yang dibuat dapat digunakan secara massal. Yang membedakan, produk-produk yang dihasilkan, terutama produk kreatif tersebut adalah ide atau gagasan penciptanya. Bahkan, aspek inilah yang bernilai paling mahal.

Dalam menyelesaikan tugas-tugas Apresiasi Prosa Fiksi yang beragam di atas, mahasiswa juga mendapatkan kesempatan belajar bekerja sama, atau berkolaborasi. Model pembelajaran seperti ini disebut oleh Johson, dkk. Sebagai model kooperatif dengan kelompok inti, baik kelompok inti kelas atau kelompok inti sekolah (2010: 91-112 ). Dalam bekerja sama, mahasiswa dituntut menjalin komunikasi yang baik, baik dalam kelompok belajarnya, maupun berkomunikasi antarkelompok belajar di dalam kelas mereka. Kolaborasi dalam hal ini dipandang sebagai suatu strategi untuk menjamin semua anggota kelompok belajar dapat berhasil dengan standar yang tinggi. Oleh sebab itu, proses berpikir tingkat tinggi (critical thingking) pun akan muncul. Empat hal ini adalah kompetensi penting yang harus dimiliki agar dapat berhasil dan eksis di era revolusi industri 4.0. Diungkap oleh Dirjen Kelembagaan Kemenristekdikti, Ali Ghufron, saat kunjungan media ke kantor Harian Umum Pikiran Rakyat (4 Mei 2018) sebagai 4C (critical thingking, creativity, collaboration, dan communication) yang dibutuhkan di era revolusi 4.0 http://sumberdaya.ristekdikti. go. Id /index.php/2018/05/04/formula-4c-untuk-bertahan-pada-erarevolusi-industri-4-0/.

Demikian capaian-capaian pembelajaran yang dapat dirumuskan dengan memperhatikan kecenderungan era revolusi industri 4.0, sebagaimana yang diamanahkan dalam panduan pengembangan kurikulum pendidikan tinggi (2018). Terwujudnya berbagai capaian pembelajaran tersebut tentu dengan strategi pembelajaran yang sejalan dengan era revolusi industri 4.0 tersebut. Oleh sebab itu, perlu pula diupayakan model pembelajaran yang dapat mengantarkan mahasiswa memiliki Capaian Pembelajaran yang telah ditetapkan. Di antara model pembelajaran yang relevan yang sedang dikembangkan adalah model blanded learning, yakni model pembelajaran yang memungkinkan pembelajaran dapat berlangsung tanpa memperhitungkan latar waktu dan latar 
tempat, dan kehadiran pengampu mata kuliah secara lahiriah. Prawoto dan Pramulia (2019:39) menyakini bahwa model blanded learning dapat meningkatkan kualitas apresiasi mahasiswa terhadap karya sastra, karena dalam model ini ditawarkan berbagai macam media agar mahasiswa kreatif mengubah karya sastra menjadi bentuk lain dengan baik.

\section{SIMPULAN}

Kurikulum Pendidikan Tinggi merupakan amanah institusi yang harus senantiasa diperbaharui sesuai dengan perkembangan kebutuhan dan IPTEK yang dituangkan dalam Capaian Pembelajaran. Capaian pembelajaran Mata kuliah yang dirumuskan pengampu mata kuliah hendaknya mencakup dimensi sikap, pengetahuan, dan keterampilan yang dapat diamati, diukur, dan dapat didemonstrasikan di akhir pembelajaran. Capaian pembelajaran pada masing-masing dimensi juga mencakup keseluruhan tingkatannya.

Capaian Pembelajaran Lulusan yang dibebankan pada mata kuliah Apresiasi Prosa Fiksi berjumlah enam CPL, terdiri atas, satu CPL sikap, satu CPL pengetahuan, satu CPL keterampilan umum, dan dua CPL keterampilan khusus. Enam CPL yang dibebankan pada mata kuliah tersebut dispesifikasikan menjadi enam CPMK, dengan satu CPMK sikap positif terhadap karya prosa fiksi; satu CPMK pengetahuan yang berkenaan dengan konsep-konsep, prinsip-prinsip, kategori-kategori, dan prosedur apresiasi prosa fiksi; satu CPMK Keterampilan Umum berupa kemampuan menunjukkan kerja mandiri, bermutu, dan terukur; dan dua CPMK Keterampilan Khusus, berupa kegiatan dokumentatif, penampilan, produktif, dan layanan jasa.

Sepuluh sub-CPMK yang dirumuskan berkenaan dengan kompetensi: 1) sikap terhadap karya prosa fiksi; 2) pengetahuan tentang konsep-konsep, prinsip-prinsip, kategori-kategori, dan prosedur apresiasi prosa fiksi; 3) mendokumentasikan karya prosa fiksi; 4) membacakan karya prosa fiksi; 5) mendongeng; 6) bercerita islami; 7) menulis antologi puisi; 8) mencipta fiksi lintasmedia; 9) membuat majalah sastra (prosa fiksi), dan 10) layanan jasa taman bacaan.

Sepuluh sub-CPMK yang dirumuskan mencakup berbagai kawasan dan tingkatan tujuan pendidikan; mencakup berbagai kegiatan dan tingkatan apresiasi sastra, bermuatan dengan kompetensi yang dibutuhkan di era revolusi 4.0, sehingga memungkinkan mahasiswa menjalankan profesi yang ada di era revolusi industri 4.0, terutama yang berbasis bahasa dan sastra.

\section{DAFTAR PUSTAKA}

Antariksa, Yodhia. (2019). Bagaimana Ria Ricis Meraih Income Rp 500 Juta/Bulan dari Iklan Youtube. Sumber: http://strategimanajemen.net/2019/06/10/bagaimana-ria-ricis-meraihincome-rp-500-juta-per-bulan-dari-iklan-youtube/ diunduh tanggal 10 Desember 2019.

Aminuddin. (2010). Pengantar Apresiasi Karya Sastra. Sinar baru Algensindo: Bandung. 
Atmazaki dan Hasanuddin. (1990). Pembacaan Karya Susastra sebagai Seni Pertunjukan. Angkasa Raya. Padang.

Baygin, M., Yetis, H., Karakose, M., \& Akin, E. (2016). An Effect Analysis of Industry 4.0 to Higher Education. 15th International Conference on Information Technology Based Higher Education and Training (ITHET) (pp. 1-4). Istanbul: IEEE.

Dick, Walter , Carey, Lou dan Carey, James O. (2001). The Systematic Design of Instruction Sixth Edition. Boston : Pearson.

Direktur Jenderal Sumber Daya Iptek dan Dikti. (2018). “Formula 4C untuk Bertahan pada Era Revolusi Industri 4.0” . http://sumberdaya.ristekdikti.go.id/index.php/2018/05/04/ formula4c-untuk-bertahan-pada-era-revolusi-industri-4-0/ . Diunduh 26 Oktober 2019.

Garjito, Dany. (2019. Berapa Gaji Tour Guide? Profesi yang Makin Dilirik Milenial. Sumber: https://www.guideku.com/travel/2019/09/01/150000/berapa-gaji-tour-guide-profesi-yangmakin-dilirik-milenial. Diunduh tanggal 11 Desember 2019.

Gunawan dan Palupi. 2012. “Taksonomi Bloom - Revisi Ranah Kognitif: Kerangka Landasan untuk Pembelajaran, Pengajaran, dan Penilaian, dalam Premiere Educandum, Jurnal Pendidikan dasar dan Pembelajaran. Volume 2, No. 02. Diunduh 20 Oktober 2019. http://e-journal.unipma.ac.id/index.php/PE/article/view/50/47

Jhonson, David W. dkk. (2010). Colaborative Learning. Terjemahan Narulita Yusron. Bandung: Nusa Media.

Kotler, P., Kertajaya, H., Setiawan, \& Iwan. (2017). Marketing 4.0 Moving from Traditional to Digital. New Jersey: Wiley.

Kementerian Riset, Teknologi dan Pendidikan Tinggi. (2018). Panduan Penyusunan Kurikulum Pendidikan Tinggi di Era Industri 4.0. Jakarta: Kementerian Riset, Teknologi dan Pendidikan Tinggi.

Prawoto dan Pramulia. (2019). "Pembelajaran Sastra Berbasis Blended Learning” dalam Efektor. Volume 6 Issue 1, 2019, 37-42. http://ojs.unpkediri.ac.id/index.php/efektor-e DOI: https://doi.org/10.29407/e.v6i1.12532. diunduh 27 Oktober 2019.

PWC. (2016). Industry 4.0: Building the Digital Enterprise. Jerman: PWC.

Saputra, Rio. (2019). Kesiapan Lulusan UHAMKA dalam Menghadapi Era Distrupsi Revolusi Industri 4.0. Sumber: http://www.riosaputra.com/2019/08/kesiapan-lulusan-uhamkadalam.html diunduh tanggal 11 Desember 2019.

Saryono, Djoko. (2009). Dasar Apresiasi Sastra. Yogyakarta: ElmateraPublishing.

Schwab, K. (2016). The Forth Industrial Revolution. Geneva: World Economic Forum.

Suwandi, Sarwiji. Tantangan Mewujudkan Pembelajaran Bahasa dan Sastra Indonesia yang Efektif di Era Revolusi Industri 4.0. https://docplayer.info/140677269-Tantangan-mewujudkanpembelajaran-bahasa-dan-sastra-indonesia-yang-efektif-di-era-revolusi-industri-4-0.html. diunduh 26 Oktober 2019. Diunduh 29 Oktober 2019. 
Sumardi. (2012). Panduan Apresiasi Cerpen untuk Siswa dan Mahasiswa. Jakarta: UHAMKA Press.

Tokopedia. (2019). Berikan yang Paling Berarti untuk yang Berani. Retrieved from Youtube: https://www.youtube.com/watch?v=AB2EJG7krek. diunduh 31 Mei 2019.

Tim Redaksi. (2019). 10 Peluang Atau Prospek Kerja Sastra Indonesia dan Gajinya. Sumber: https://www.renesia.com/10-peluang-atau-prospek-kerja-sastra-indonesia/

Tim Redaksi. (2019). Penulis. sumber : https://campus.quipper.com/careers/penulis diunduh 10 Desember 2019.

Tim Redaksi. (2019). Fantastis, 4 Penulis Indonesia Ini Kaya Raya dari Hasil Menulis Novel. https://www.idntimes.com/hype/fun-fact/muro/fantastis-4-penulis-indonesia-ini-kaya-rayadari-hasil-menulis-novel-c1c2/full diunduh tanggal 12 Desember 2019.

Wurianto, Arif Budi. (2019). "Literasi Bahasa dan Sastra Indonesia menuju Kewirausahaan Profesi di Era Revolusi Industri 4.0 dan Society 5.0 (Peluang dan tantangan) dalam Prosiding SENASBASA, Edisi I tahun 2019, E-ISSN 2599-0519. http://researchreport.umm.ac.id/index/SENASBASA. Diunduh 26 Oktober 2019.

Sugono, Dendy. (2014). Peran dan Kekuatan Bahasa Indonesia dalam Industri Kreatif Kebahasaan. Jakarta: Badan Bahasa.

Wardani, I. G. A. K. (1981). Pengajaran Apresiasi Prosa. Jakarta: Depdikbud.

Yandianto. (2014). Apresiasi Karya sastra. Bandung: M25.

Zamhari, S.Kom.I. (2018). 16 Prospek Kerja Jurusan Bahasa dan Sastra Indonesia Paling Cemerlang Abad Ini. https://www.academicindonesia.com/jurusan-bahasa-dan-sastraindonesia/ diunduh 28 Oktober 2019. 